\title{
Dying YOUR OWn Way?
}

A Comparative Approach to

Mortality as a Religious Identity

Marker IN BRITISH IsLAM ANd BRITISH

\section{JUDAISM}

\begin{abstract}
Dr Marta Dominguez Diaz is an anthropologist of religion who specializes in the study of transnational Sufism, and has also conducted research on ritual aspects of Islam and Judaism in a comparative perspective. Marta held a Junior Research Fellowship at the Centre for the Study of Muslim-Jewish Relations-Woolf Institute between 2009 and 2012, a study in which she explored religious variations in attitudes towards death, dying and grief among Muslims and Jews in Britain. She is currently the Assistant Professor of Islamic Studies at the University of St Gallen, Switzerland.
\end{abstract}

\begin{abstract}
This article explores how two religious traditions, Judaism and Islam, confer meaning on the phenomenon of mortality, and it examines how their adherents seek to make sense of death in twenty-first century Britain. This research scrutinizes the religious identities of these two groups within the context of British multiculturalism, and it proposes approaching the manners in which death is perceived and experienced by Muslims and Jews as identity markers. The article argues that death issues contribute to the processes of collective labelling, self-perception and definition, through the perspective of religion. This inquiry will try to elucidate how the study of doctrines and practices to do with death can provide a meaningful platform for exploring identity boundaries. What does it mean to be a Jew or a Muslim in Britain today? Can the ways in which Jews and Muslims relate to mortality help us to answer this?
\end{abstract}


Keywords: death - religious aspects; Islamic studies - rituals and practice; Jewish death customs; Jewish studies - rituals and practice; Muslim death customs.

\section{Introduction}

Arguably, the central accomplishment of any culture is its capacity to give sym-

bolic order and meaning to human mortality. (Kearl, 1995: 5)

This article examines how members of these two religious communities apprehend death, and it compares the narratives built by Muslims and Jews, who have to deal with the realities of dying and bereavement, whether it be in their personal lives or in circumstances connected with their profession. The data for this study has primarily been collected by conducting semi-structured interviews with people who live in the London area. In total 42 Muslims and 36 Jews were interviewed. The project sought to understand whether or not a religion confers upon its practitioners a "special" approach to death, one which is not shared with other people. In other words, how do Islam and Judaism inform the ways Muslims and Jews think about death? In order to identify such features, it was considered important to study a sample of respondents which was representative of the intra-religious diversity of both faiths. The research could not be limited to a particular sub-grouping in either religion, and had to include members drawn from the bigger branches and denominations.

The 41 Muslim respondents were comprised of 35 Sunnis and 7 Shi' ites. ${ }^{1}$ of the Sunnis, 12 described themselves as Deobandi, 11 as Barelvi, 5 categorized themselves as Sufis, and 6 considered that their religious identity did not fit into any subcategory and preferred to refer to themselves just as Muslims. Of the 7 Shi' ite Muslims interviewed, 5 defined themselves as Twelvers, and 2 as Ismailis. ${ }^{2}$ Of the 36 Jews interviewed, 15 were Orthodox, 6 were Haredi, 4 belonged to a Reformed synagogue, 4 defined themselves as Liberal, 1 was Sephardic, 1 Masorti,

1. Muslims generally have no problem in publicly stating whether they are Sunni or Shi'ite. It can, however, be difficult to identify any more nuanced religious affiliation. Sometimes they do not explicitly claim to belong to a particular branch of Sunni or Shi'ite Islam. In order to overcome this, respondents were presented with a number of categories in a multiple-choice questionnaire and asked which "Muslim religious identity" they felt most comfortable being identified with.

2. We have tried to include people who are representative of what are generally considered to be the main "factions" of British Islam. Although numbers are very difficult to estimate, we have taken what are considered to be the official estimates for the City of London. For further information about these estimates, see the Mehmood Naqshbandi guide commissioned by the London Police Authority on Islam in Britain and made available online at: htp://guide.muslimsinbritain.org/guide3.html\#_ftn1. 
and 5 described themselves as Secular Jews. ${ }^{3}$ This article proposes a comparative approach to Judaism and Islam, and it argues that this will shed light on certain facets of the ways in which Jews and Muslims understand and cope with death.

\section{Dying your Own Way? Mortality as a Religious Identity Marker in British Islam and British Judaism}

There are many points of comparison between Judaism and Islam. They are both monotheistic religions rooted in the Semitic tradition, which has resulted in them having remarkably similar religious structures, in theological terms particularly, but also in terms of jurisprudence and religious practice. They evolved around a monotheistic ethos based on the idea of transcendence and the unity of God, Who is envisaged as having revealed a way of life and a set of values for humanity's benefit. Christianity, on the other hand, has largely retained a Trinitarian approach to monotheism.

Although the three faiths are considered to be the "religions of the book," the role of the Scriptures in Judaism and Islam is different to the role of the Scriptures in Christianity. The Islamic and Jewish jurisprudential codes of conduct the Sharia and Halakha - also bear interesting parallels, particularly in regard to the content of some of their injunctions, to their logic and structure, and to the ways that they are followed on a practical level. The emphasis placed by Jews and Muslims on orthopraxis (appropriate conduct linked to a religious ethos and ritual performance) has no parallel among Christians. Whereas in Christianity repentance is sought in order to achieve individual salvation from original sin, in Islam and Judaism the ultimate goal is to behave religiously in accordance with the commandments of the Scriptures. In order to accomplish this, the religious rationale encourages people to maintain ethical conduct, correctly perform rituals, and fast and pray when required.

Ways of conceptualizing time and the human lifecycle, together with the meanings attached to the process of dying, to the moment of death, and to grief and bereavement, also present interesting parallels. These provide meaningful grounds of comparison and contrast between the two faiths, and justify a comparative approach. Christianity shares with these faiths a teleological sense and certain aspects of their eschatological ethos, but it does not assign the same importance to religious law that the Sharia and Halakha have acquired in Islam and Judaism.

3. "Key Trends in the British Jewish Community Report," April 2011, commissioned by the Institute for Jewish Policy Research. 
The importance of religion to both Muslims and Jews is attested to by the existence of various visible identity markers, some of which were common amongst the people interviewed for this study. From clothing and hairstyles to which day of the week is reserved for rest, they are all important indicators of religious distinctiveness in the context of a multicultural Britain. Muslims and Jews, as examples of minorities in multicultural environments, have both been studied in order to shed light on the - often mutually reinforcing - correspondence between religious affiliation and other identity categories, such as ethnicity (Christiano, Swatos and Kivisto, 2008: 153).

Some of the interviewees who participated in this study not only dress and wear personal adornments which distinguish them, but they also have distinctive eating habits and, importantly, a lifestyle that includes a plethora of specificities that they do not share with the rest of society; it is in this sense that Judaism and Islam operate as identity boundary markers, in a way that is closely interrelated with ethnicity. ${ }^{4}$

This confers upon British Muslims and British Jews respectively a certain degree of distinctiveness which militates against their assimilation, so that in certain respects they remain insular, living their lives within their communities, though often negotiating patterns of engagement with mainstream society. Islam and Judaism in Britain encompass numerous distinct groups, yet, although diverse, the majority of Muslims and Jews in Britain seem to like being identified by their religious affiliation, which is why studying these groups in light of their religious identity makes more sense than studying them according to other cultural traits. British Jews and Muslims are examples of how religion underlies identity construction in crucial ways (Anwar, 1998). ${ }^{5}$

Furthermore, the fact that both groups identify the other as "the other," "minority monotheism" implies their relational situation; it puts them in a position in which they are both doctrinally somehow close to Christianity, although distant from it when it comes to their societal visibility and representation Christianity being the most widely followed religion in the country. Although the UK is home to the second largest Jewish population in Europe, and has the fifth largest Jewish community worldwide, in the 2001 census British Jews only

4. Ethnic identity is a social aspect that has received significant theoretical as well as empirical attention (e.g. Phinney et al., 2001; Verkuyten, 2005). Studies dealing with the British milieu are abundant and often take Muslim British South Asians as case studies to underline the ways in which identity is constructed (e.g. Ghuman, 2003; Hutnik and Street, 2010; Robinson, 2009).

5. There are recent studies conducted among British Pakistanis which demonstrate that it is in fact religion and not ethnic identity which takes precedence over all other identity markers (Jacobson, 1997).

\section{equinoxonline}


accounted for 0.5 per cent of the total population. Muslims by contrast constitute the largest religious minority in the country, in the same census they represented 2.7 per cent of the total population. ${ }^{6}$

In terms of ritual, Judaism and Islam bear remarkable similarities, features which do not appear in Christian rites. Ritual practices of prayer, fasting and almsgiving are certainly central to all three monotheistic faiths, but there is a particularly striking similarity between Islam and Judaism with regard to certain dietary regulations, and also various notions to do with bodily pollution and ritual formulae aimed at purification, features which do not extend to Christianity. Although Jewish and Muslim mortuary rites differ in some aspects, they also show remarkable parallels. For example, most Jewish and Muslim denominations and sects believe that a body should be buried as soon as possible following the death.

They are also in accord in that, prior to the burial, a corpse should be clad in a white cloth following a ritual bath, which is performed in a similar manner in both cases. The aim of the entire process is the same for the two religions - to achieve spiritual cleanliness, a concept that in both traditions receives the name of tahara. Restoring tahara in Judaism and Islam involves a similar three-staged process; Jews refer to rechitza, the process of the ritual washing of the body, and for Muslims a similar process is called ghusl. After washing, the body needs to be shrouded in a white cloth, in a ritual dressing process that Jews will designate by the Hebrew term halbasha. Similarly, it is mandatory for Muslims to wrap the deceased's body with a clean white cotton shroud before burial, which is known by the Arabic term takfin.

At a societal level, there are additional similarities between Muslims and Jews when it comes to issues regarding death and the end of life. The majority of Jews and Muslims who participated in this study - with the exception of those who refer to themselves as "secular Jews" - have declared that they often identify themselves with reference to their religion, before using other identity markers such as age, gender, nationality and so on.

One of the most remarkable findings to emerge from the data collected during this study is that for British Muslims and British Jews, in consonance with the

6. Data obtained from the 2001 UK Census, see http://www.ons.gov.uk/ons/guidemethod/census/census-2001/index.htm

7. A person who identifies him/herself "culturally" with Judaism, but is not observant of its religious dimension. The idea of secular Judaism comes from the assumption that Judaism can be considered not only a religion but an ethnicity (Sharot, 2011). Secular Judaism has been defined as a distinct cultural phenomenon related to Jewish secularization - a historical process of divesting cultural elements common among the Jews (which can include music, cinema, literature, food, and so forth) from their religious beliefs and practices (Beit-Hallahmi, 2007). 
rest of society, the topic of death seems to be quite taboo, a subject to be avoided rather than dwelt upon to the same extent as other subjects. In fact this seems to be one of main features differentiating British Muslims from Muslim cultures in other parts of the globe (e.g. Abu-Lughod, 1993). In the case of Judaism, it is what differentiates the majority of British Jews from particular denominations (e.g. Haredi Jews). ${ }^{8}$ A Muslim and a Jewish respondent acknowledged that this is not as common a topic of discussion in religious circles as one might imagine. What emerges from the printed materials that Jewish and Muslim communities across London produce accords with this theory, as does a browsing survey of the archives of the most widely read Muslim and Jewish newspapers in the UK, the Muslim News and the Jewish Chronicle. References to issues surrounding death tend to be scarce, particularly when compared to the frequency with which other subjects are covered, such as faith schools, religious intolerance, anti-Semitism, Islamophobia and so on.

Although changes may have taken place in society that seem to indicate a more open attitude towards death and dying (such as improvements in palliative care, the consolidation of the hospice movement, the relative acceptance of the figures of the hospital chaplain and the bereavement counsellor), ${ }^{9}$ the thesis that Western European societies are "death-denying" is still very much in vogue (Zimmermann and Rodin, 2004). Increasingly though, there are voices which question whether there can be such a thing as a society which is not death-denying in some sense (e.g. Kellehear, 1984; Walter, 1991; Seale, 1998).

Studies which assert the "death-denying" attitude of society follow Ariès (1974), who became famous worldwide for analysing the processes through which the cultural conception of death in Western Europe has been gradually transformed, from a social model in which personal identity depended principally upon the community, to the more individualistic ethos by which the whole experience of dying and death itself becomes remote from ordinary experience. More recently academics have claimed that we turn a blind eye to death by consistently trying to make it invisible, and by approaching it in a routinized, highly medicalized manner that prevents us grasping it in its human and biological reality. Green has written lucidly on this (2010: 211). ${ }^{10}$

8. For an introduction to their approach see the chapter on funerals at Heilman (2000).

9. On the contested role of hospital chaplains, I wrote an article for the Times Newspaper that can be read at: http://www.cis.cam.ac.uk/Life\%20and\%20Death\%20Times\%20article.pdf

10. For a quite old yet very systematic and useful review of the most relevant sociological literature on the thesis of "death denial," see Kellehear (1984). 
The approach to death and its related issues, which has been taken by British Muslims and Jews, seems to be not very different from that taken by the rest of society. Having said that, however, there are two points of interest which should be mentioned; first, both Jews and Muslims see themselves as people who evince a greater concern with death than do members of the wider society. Various Muslim interviewees suggested that Muslims talk more openly about death than non-Muslims, and that in Muslim circles death is not a subject to be avoided. One interviewee argued that Muslims keep death present at all times because the Prophet Muhammad encouraged them to do so. He said that the Prophet asked that remembrance be made of death in order that the important things of life should be valued and focused upon.

People may see themselves as being able to talk openly about death and to have death present at all times, but this does not necessarily equate with them being open to the expression of feelings and emotions connected with death. Although crying is often recognized as a normal reaction, as are other ways of releasing emotion, such as wailing out loud, these practices are permitted only in moderation. Some Muslim interviewees told me that women are generally discouraged from participating at funerals unless they are able to refrain from wailing. According to a large proportion of both female and male interviewees, Islam does not condone public expressions of grief, particularly wailing at funerals. It is generally held that such behaviour is a pre-Islamic practice which Islam came to countervail. It is interesting to note that in Judaism, the contrary is often taken as mandatory, wailing for the deceased being a mark of respect, and interviewees explained that in orthodox circles the deceased's family sometimes even hires "professional wailers" to attend the funerals of their deceased relative, a practice believed to be very antique and preserved to this day. However, I could not find any evidence for the existence of professional eulogizers in modern times.

The public expression of grief is generally discouraged, although quiet and almost silent weeping for the dead is accepted and often occurs among the bereaved, both male and female. Interestingly, the findings of the present study indicate that Sunni Muslims appear to have made the non-expression of grief particularly in contexts where it would seem natural to express it - a hallmark of Sunni identity. Shi'ite interviewees did not emphasize the obligation to reprimand expressions of grief such as loud wailing, shrieking, beating of the chest, or the tearing of hair or clothes. These practices actually constitute an identity marker of Shi'ites worldwide when, during the month of Muharram, some Shi'ite Muslims ritually perform such expressions of emotion during the well-known period of mass mourning for what Hussain is said to have undergone during the battle of Karbala (680 AD). The Sunnis, on the other hand, celebrate the occasion

\section{equinoxonline}


in a quieter manner. For them, the expression of emotion due to bereavement can adversely affect one's behaviour, but such behaviour is to be censured only rarely, as a famous hadith emphasizes. ${ }^{11}$

To say that the majority of Sunni Muslims consider wailing to be forbidden by their religion is not to say that people do not wail at funerals. It is easy to confuse what respondents say about what Islam prescribes with what people really do. Although many interviewees acknowledge that open and loud expressions of grief are discouraged, almost all acknowledge having seen people, especially women, wailing at funerals. This underlines the differences between the actual case-studies, which are descriptive, and what people consider to be normative, which is prescriptive - dictating how people should behave. This is an indication of how important it is, not only to consider the beliefs of a religious tradition, but also to contrast them with the lived experience of individuals and communities. In this case, the stated belief - that the emotions should be contained - is the rationale underlying the rules by which grief is "policed" (to refer to this form of collective self-regulation with a term frequently used by scholars, for example, Walter, 1999); such rules are the guidelines for public performances. According to interviewees, these guidelines sometimes coincide with what mourners do, but sometimes they overtly contradict it.

Jews also often perceive themselves as people who go against the death-denying attitude of society. As one Jewish respondent put it:

Death is a natural part of the life cycle; this is a Jewish way of looking at it, and it contrasts with the neglect and omission that it often suffers when experienced in hospitals, care homes and in general in non-Jewish places and families. ${ }^{12}$

The idea that Jews are more concerned about death than non-Jews is something that the majority of Jews interviewed shared. "We Jews do care about death more than the rest of people," a Jew who had his mother interned at a hospital in North London pointed out.

I am worried about how she is going to be treated at the final moments of life, because most probably the doctor will not be a Jew, and we Jews have more respect for the dying, our religion tells us how to behave properly in these circumstances.

Again it should be emphasized that this is a self-perception, and it is one that is difficult to measure against the reality. However, the lack of references to death in the literature produced by the two communities would seem to indicate that on the subject of death and dying they may not be very different from the

11. Sahih Muslim 23, 375-93.

12. To preserve confidentiality I have omitted the names of interviewees.

\section{eevinoxonline}


death-denying mainstream. Be that as it may, what is of overriding relevance here is that the way they perceive their attitude towards death and issues to do with death is used by British Muslims and Jews as an identity marker, as something that supposedly characterizes them in opposition to the rest of society.

This illustrates a fascinating dimension of minority religious identities in the context of multicultural societies, which is that such identities are formed, not in an essentialist way (meaning that people are essentially this way or that way), but rather through a "conversation" between the religious group and mainstream society. Thus, religious identities occur in a contextualized manner and are the result of the ways in which the religious group relates to the context in which it exists. As Taylor puts it when referring to minorities (though not only religious ones):

My discovering my own identity doesn't mean that I work it out in isolation, but that I negotiate it through dialogue, partly overt, partly internal, with others. That is why the development of an ideal of inwardly generated identity gives a new importance to recognition. My own identity crucially depends on my dialogical relations with others. (1997: 103)

By believing that society is death-denying, and that they are not, both Muslims and Jews are inadvertently using the issue of death to build the boundaries of identity - boundaries which they need in order for them to be recognized by the rest of society.

Going beyond the question of self-perception, the impression one gets from the interviews is that Jews do reflect on death more often than Muslims. Sometimes they reflect on the distinctive fears which arise when thinking about death, on other occasions they think about the dying process or the experience of pain and how to cope with it. Muslims, on the contrary, were more reluctant to discuss issues of this kind. One Muslim respondent argued that Muslims tend to focus on aspects of their religiosity that relate to young people, whereas Jews are keener to deal with issues that affect people of all age groups in their communities, including the oldest.

The fact that Muslims seem less concerned about the issues that surround death might be - as an imam from London suggested to me - a direct consequence of the fact that Muslims in Britain are mostly young and occupied with issues that affect the young, whereas Jews, on the contrary, are on average older than the majority of the population. ${ }^{13}$ Another respondent, aware of the fact that there are

13. 52 per cent of British Muslims are under 25 (compared to 31 per cent of the population as whole). By contrast, 24 per cent of British Jews are over the age of 65 (compared to 16 per cent of the general population). Whereas the average age of Muslims in the UK is 28 years old, the average age of Jews is 41 . In the 2001 census Jews were the only group in which the number of persons in the 75-plus cohort outnumbered those in the 65-74 cohort.

\section{equinoxonline}


very few Muslim hospices, particularly when compared to the number of Jewish ones, argued that Muslims consider death to be a family matter, and the arrangements about how to live at the end of life, where to be buried and so on are generally discussed within the household. He further argued that Muslim families are reluctant to place their elders in hospices, but prefer to take care of them at home. Out of this study's 42 Muslim respondents, 16 suggested that to send an elderly parent to a care home is considered morally unacceptable, although some were not sure whether this attitude could be attributed to their religion or to their South Asian cultural background. ${ }^{14}$

Their "minority condition" together with a certain amount of shared theology means that Jews and Muslims are positioned quite near each other in a variety of contexts. To illustrate this proximity with regard to the issue of death, both often believe that autopsies should not be permitted unless absolutely necessary, because autopsies are considered to be a human-authorized mutilation of a body believed to be owned by God. For this very same reason cremations are strongly disapproved of. Because both Jews and Muslims believe in the need to protect the "integrity" of the corpse, some groups within these two religions have campaigned together to obtain the right to use MRI and CR scans - seen as non-intrusive ways to determine the cause of death - in preference to the autopsy, which is generally the first option when the cause of death is required by law to be determined and when it cannot be determined by other means. ${ }^{15}$

Another reason autopsy is considered unlawful is because it delays burial, which according to both Islamic and Jewish religious law should occur as soon as possible after death. The Torah indicates at parshat ki teitzei that it is forbidden to leave a dead person unburied overnight (lo talin nivlaso all ha'etz'), instead she or he should be buried as promptly as possible. This Jewish custom illustrates the biblical concept of "dust you are, and to dust you shall return" (Genesis 3:19). Among Jews, leaving a body unburied is considered a moral indignity, as it seems it was in Ancient Israel (1 Kings 14:11, 16:4; Jeremiah 22:19). Even a criminal who has been executed by hanging deserves an appropriate burial, and this shall occur as soon as possible according to the Talmud (Sanhedrin $46 \mathrm{~b}$ ). ${ }^{16}$ Deuteronomy 21:23 states

14. There are 36 Jewish care homes in Britain in total, 22 of which are in the Greater London area. The largest, Nightingale House in Wandsworth, is situated ten miles from Barnet.

15. See how years of joint campaigning have resulted in alternative post-mortem techniques being authorized whenever possible, htp://www.timesonline.co.uk/tol/news/uk/ article6140789.ece

16. The Sanhedrin is one of the ten tractates of the Seder Nezikin - which is a part of the Talmud that talks about damages (civil and criminal proceedings). It originally formed one tractate with the part called the Makkot, which also deals with criminal law.

\section{equinoxonline}


that, "His corpse shall not remain all night on the tree, but you must bury him the same day." The Jewish tradition has generalized from this injunction to all burials; in some cases the burial is delayed overnight and sometimes even a bit longer, in order that there may be time to acquire proper shrouds or a coffin, or to allow close relatives who live far away to journey to the funeral. All interviewed people agreed that major delays are considered to be dishonouring to the deceased and are very rare.

In Islam, the fact that graves are mentioned several times in the Quran and the hadith, ${ }^{17}$ is taken to indicate support for internment in the earth. What appears in the Muslim sources repeatedly are references to "the torments of the grave" - the idea that if one does not behave faithfully in life one will be tormented in the grave in the time of Barzakh. ${ }^{18}$ For example, the Quran states that, "The grave is like patches of dark night! o people, if you knew what I know, you would weep much and laugh little. O people, seek refuge with Allah from the torment of the grave, for the torment of the grave is real" (Sura Ghafir). A hadith declares that Aisha said that a Jew told her, "May Allah protect you from the punishment of the grave," so she asked the Prophet whether there was punishment in the grave to which he nodded. ${ }^{19}$

Muslim interviewees, in contrast to what is common among Jews, all agreed that it is not usual for them to delay the burial in order to wait for relatives who live far away to arrive. Once dead, the corpse should undergo ritual preparations promptly and be buried as soon as possible. An interviewee reported that this widely spread commandment is supported by the hadith in which the Prophet is said to have told Abu Hurayra, "hasten the funeral rites." ${ }^{20}$ Another interviewee argued that seeing the deceased's body as little as possible helps to minimize the pain, and discourages loud and "exaggerated expressions of grief."

It is generally stated in the scholarship that Muslims are always buried, never cremated (e.g. Gatrad, 1994), although the sources do not clearly or explicitly condemn cremation. The majority of interviewees, however, considered that funeral rites are performed as a sign of respect and are a way of honouring the deceased's

17. Hadith is the term used to refer to the sayings and acts attributed to the Prophet Muhammad. Hadith are regarded as important sources of behavioural guidance; most of these sayings were collected, evaluated and gathered into large collections during the eighth and ninth centuries.

18. Barzakh is the intermediate state in which the soul of the deceased is transferred across the boundaries of the mortal realm into a kind of "cold sleep" where it will rest until the moment of the Qiyama (Judgement Day).

19. Sahih Bukhari, 23, 454 .

20. Collected in five of the most renowned compendiums of hadith: Sahih Bukhari 2, 401; Sahih Muslim, 2, 2059; Sunan Abu Dawud, 2, 3153; Sunan Ibn-i-Majah, 2, 1477. 
body, and that cremating it would amount to the opposite. Some of the interviewees were of the belief that the body continues to feel after the soul has left it, and that therefore cremating it would inflict a great deal of unnecessary pain. There are no exact figures for the percentage of Muslims who choose to be cremated, but the small sample considered for this study would seem to indicate that cremation is a very rare practice among British Muslims. None of the interviewees had ever met a Muslim who intended to be cremated.

On the other hand, there is more data available on British Jews in relation to cremation, and it suggests that it is not as uncommon among Jews as it is among Muslims. Although Judaism equally condemns the practice of cremation, the 2007 Report of the Board of Deputies of British Jews estimates that 11 per cent of the total number of deaths recorded among British Jews were cremations. ${ }^{21}$ It seems reasonable to suggest that actual numbers of cremations among Jews are much higher than these figures suggest because all those represented in the survey are linked to a Jewish synagogue through formal Jewish lifecycle rituals, such as circumcision, marriage, burial or cremation. It might well be that liberal Jews who are not members of a synagogue - like some of those interviewed in the present research - tend to be less religiously observant and more likely to choose cremation as a form of disposal. The findings of this study nonetheless indicate that Jews from all denominations equally see cremation as a non-religious practice.

The vast majority of the Jews interviewed argued that "cremation is not a religious but a secular act," and that among Jews "burying is the rule and cremation an exception." One respondent presented an illustration of this in these terms: "Cremation is not part of our tradition but an individual choice. It is atypical for a religious person to be cremated." However, the only two Jews interviewed that declared that they may consider cremation as a possible option, considered themselves to be "religious in some way but definitely not in the traditional way." Cremation is therefore seen by the community as a non-religious practice, yet one might reasonably conclude that it may be a trend not only chosen by those not professing any sort of religious view, but by Jews who experience Judaism in new, alternative forms of religiosity. Additionally, statistics indicate that although the majority of those who choose to be cremated are liberal Jews, there is a smaller proportion of Reform Jews who also opt for this form of disposal.

When someone dies, a number of decisions need to be made, often within a very short period of time. "Caring about death" meant, for most of the Jews interviewed, thinking about the arrangements that need to be made well in advance

21. Information available online at: http://www.boardofdeputies.org.uk/file/CommuhityStatistics2007.pdf accessed 29th November, 2010. 
and making sure that there is agreement about what the wishes of the dying person are. One of the aspects that is most remarked upon by Jews in relation to such plans is the buying of the burial plot. Most of the Jews that have taken part in this study have stated that they "belong" to a synagogue; this means that they pay an annual fee which contributes to the maintenance of the congregation (among other things), and also gives the person the right to be buried in a Jewish cemetery that is owned by that synagogue.

However, it is important to bear in mind that although membership of synagogues may be remarkably high among British Jews, this does not necessarily mean that there are high levels of religious attendance. There are a large number of people who pay the annual synagogue fee but attend on only very few occasions - this is true of almost a quarter of the Jews who participated in this research. They are very clear that they pay the fee in order to have the right to be buried in a Jewish cemetery. Judaism, in this regard, seems to be remarkably similar to Christianity. Even for those not overtly religious in their everyday lives, the three rites of passage (birth/baptism, marriage and death) are times of contact with institutional religion. ${ }^{22}$ of the 36 Jews in this study, only 6 were not affiliated to a synagogue and had no clear idea about what arrangements will be made in the event of their death.

Islam in this regard is quite different. Of the 42 Muslims interviewed, only 3 admitted to donating money to a mosque on a regular basis. Donations are generally seen as something that should be given to the poor (zakat) and not to a religious centre or institution. Among the Muslim respondents, donations made on a regular basis were contributions to charities and not to mosques. Thus, the only sense in which Muslim respondents could be considered "members" of a mosque is by regular attendance. Some of the Muslims interviewed go regularly to the same mosque, whereas others had changed their place of worship in accordance with the location of their workplace, university or home; some start going to a different mosque when they move home, others keep going to the same one. In some cases, those who were regular attendees at a particular mosque had made donations to the mosque, but such gifts were made only occasionally and with a specific purpose in mind - such as the replacement of facilities, or the building of a madrasa - and they were not connected in any way with a burial site. Although mosques might have agreements with city councils with regard to cemeteries, they do not directly own burial sites, so the relationship that in exists in Judaism between cemeteries and synagogues finds no parallel in the case of Islam.

22. For further information see, British Religion in numbers http://www.brin.ac.uk hews $/ p=840$

C Equinox Publishing Ltd 2013

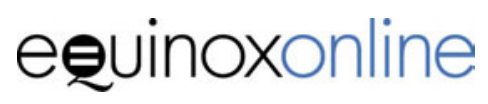


When someone dies, the family pay an "internment fee" which is included in the costs that have to be paid to the cemetery. Several of the Muslim interviewees, however, have complained about being charged for this. In Muslim circles, funeral arrangers tend to be people from the close community, friends or relatives, none of whom charge anything for carrying the body and burying it in the ground. It is seen as morally improper to charge money to carry out such duties, even if the person was not someone very close. Sometimes people will accompany and intern the body of someone who had no family or who had migrated to Britain recently and does not have anyone else to do it. In some cases, people will even do it for a deceased person whom they have never met, because they are mindful of the circumstances of living abroad, far from one's home country, in situations of solitude. Two Muslim respondents told me that they had carried the bodies of people they did not know, for reasons to do with religious solidarity:

I did it because he is a Muslim and he had no family in this country. I know this sounds strange to a non-Muslim, but a Muslim would not find it rare to treat a Muslim like he is your brother, even if you did not know him.

Another respondent considered it a religious duty. Yet for another, the religious duty extended to include non-Muslims:

Muslims shall accompany people who is dying. When non-Muslims are dying they have to be present in order to introduce them to Islam. The only occasion in which they shall leave is when acts that Islam consider sinful are being committed, for example drinking or consuming drugs.

He went on to tell me the story of how the Prophet Muhammad visited a Jewish youth who was dying, and that he sat with him and proclaimed: "Embrace Islam, embrace Islam." The boy, the story goes, looked at his father as if to ask for his permission, and his father nodded, asking him to obey the Prophet. The boy pronounced the shahada ${ }^{23}$ and died immediately thereafter. Muhammad then said: "Praise Allah who has saved him from doing worse," and asked his companions to pray the janaza prayer, characteristic of Muslim funerals, over him. Not all Muslim respondents considered this proselytising impulse to be a religious duty, in fact some of them looked quite shocked when I told them this story. On the whole, however, they considered it an honour to attend the funerals of those who have accompanied us in life, no matter what their religious orientation. Most of the respondents thought it a positive thing to help at funerals, to assist with washing

23. The shahada is the Muslim declaration of belief in the oneness of God (tawhid) and acceptance of Muhammad as the last prophet sent by God. In Islam a single honest recitation of the shahada in Arabic is all that is required to become a Muslim.

\section{equinoxonline}


the body and burying it. Some said attending funerals was recommended, even funerals of people one had not met in life.

Amongst Jews there is greater variety, in some cases "internment" is carried out by members of a professionalized "burial society" (chevra kadisha) who do charge a fee for their services. ${ }^{24}$ Among some orthodox and the majority of ultra-orthodox Jews, some of the burial societies have not yet been professionalized, membership is voluntary and the societies are often well-attended by members of their religious communities - which tend to be small and close-knit. Being part of the chevra kadisha is perceived as a laudable task because it is considered a chesed shel emet (a good deed of truth). ${ }^{25}$ One respondent mentioned that they were having some difficulty recruiting new members, as younger people, even those committed to their religion, are not very interested in joining the society. Interviewees from orthodox and ultra-orthodox communities, on the other hand, do not seem to have this problem. With voluntary burial societies there are no payments to be made. In all cases, the members of the burial society will be in charge of the three preparatory stages that take place before burial, which are performed for reasons of cleanliness and ritual purification.

Yet another dimension of their respective practices that reveals a similar approach to death by both Muslims and Jews, is that in both communities, those who wash and intern the corpse follow rigorous gender etiquettes that are remarkably close. The preference in both cases is for the deceased to be washed by people of the same sex, although a woman is permitted to wash a deceased man if he was her husband or son, whereas men are not allowed to wash women, even if the deceased was a relative. This is generally held to be because of the prohibition of seeing a woman naked, although some interviewees believed that it is not forbidden to see your wife naked. Apart from small divergences in understanding and minor disagreements, the corpse of a man will be prepared for burial by men, and that of a woman by women. No matter what sect, orientation, or level of religious commitment within Islam or Judaism, this part of the ritual is generally respected and performed in the same way by all the groups and sub-branches.

24. A chevra kadisha is an organization of Jewish men and women who prepare the bodies of deceased Jews for burial according to the requirements of Jewish law. An interesting exploration of the process of professionalization of this institution through a case-study in London is provided by Schneider (1991).

25. The expression is taken from Genesis $47: 29$, a passage in which Jacob asks his son Joseph to do him a "true favour" and Joseph promises his father to bury him in the Land of Israel. Some, though very few, Jews take this as a commandment and ask to be buried in Israel, but most of them do not. None of the interviewees did and only one reckoned to know someone who wishes to be buried there.

\section{eevinoxonline}




\section{Conclusion}

In conclusion, this research indicates that death is something that needs to be understood beyond its biological dimensions, primarily as a social event, and one that contributes to the building of the identity of religious groups. In this study of Jews and Muslims in the London area, the ways in which death is understood, felt and experienced provides interesting identity markers that become key group boundaries in the context of multicultural Britain. This article has shown that there are certain similarities between Judaism and Islam in the management and handling of death. Certain aspects have to do with their theological closeness and similarities of ritual, whilst others seem to result from the ways in which the two groups relate to the society in which they live.

This study illustrates how religious identities are constructed in a dialogical way, always incorporating, reacting against, or marking the differences between the ways we do it and they do it. For example, Muslims and Jews appear to have incorporated an attitude to death which seems quite prevalent in the wider society, and thus they have made a taboo of it. Similarly, among secular Jews, the increasing popularity of cremation seems to evidence the strength of assimilationist trends among certain sections of the group. Yet both Muslim and Jewish perceptions of their own religions indicate that they see themselves as more concerned with death than the rest of people, which contributes to their distinctive identities. The ways they handle death, ritual washing, funerals and internment are sets of features that contribute towards the distinctiveness of these two groups.

\section{References}

Abu-Lughod, L. 1993. "Islam and the Gendered Discourses of Death," International Journal of Middle East Studies, 25, 187-205. http://dx.doi.org/10.1017/S0020743800058487

Alexander, J. 2001. “Theorizing the 'Modes of Incorporation': Assimilation, Hyphenation, and Multiculturalism as Varieties of Civil Participation," Sociological Theory, 19, 23749. http://dx.doi.org/10.1111/0735-2751.00139

Anwar, M. 1998. Between Cultures: Continuity and Change in the Lives of Young Asians. London: Routledge.

Ariès, P. 1974. Western Attitudes toward Death: From the Middle Ages to the Present. Baltimore: Johns Hopkins University Press.

Beit-Hallahmi, B. 2007. “The Secular Israeli (Jewish) Identity: An Impossible Dream?," in B. A. Kosmin and A. Keysar, eds, Secularism and Secularity: Contemporary International Perspectives. Hartford: Institute for the Study of Secularism in Society and Culture, 157-65.

Christiano, K., P. Kivisto and W. H. Swatos. 2008. Sociology of Religion: Contemporary Developments. Lanham, MD: Rowman \& Littlefield.

Gatrad, A. R. 1994. "Muslim Customs Surrounding Death, Bereavement, Postmortem Examinations, and Organ Transplants," British Medical Journal, 309, 521-23. http://dx.doi. brg/10.1136/bmj.309.6953.521 
Ghuman, P. A. S. 2003. Double Loyalties: South Asian Adolescents in the West. Cardiff: University of Wales Press.

Green, L. 2010. Understanding the Life Course: Sociological and Psychological Aspects. Cambridge: Polity.

Heilman, S. C. 2000. Defenders of the Faith: Inside Ultra-Orthodox Jewry. Berkeley: University of California Press.

Hutnik, N., and R. C. Street. 2010. "Profiles of British Muslim Identity: Adolescent Girls in Birmingham," Journal of Adolescence, 33, 33-42. http://dx.doi.org/10.1016/i edolescence.2009.05.016

Jacobson, J. 1997. "Religion and Ethnicity: Dual and Alternative Sources of Identity among Young British Pakistanis," Ethnic and Racial Studies, 20.2, 238-56. http://dx.doi.org/10 1080/01419870.1997.9993960

Kearl, M. C. 1995. "Death and Politics, a Psychosocial Perspective," in H. Wass and R. A. Neimeyer, eds, Dying, Facing the Facts. London: Taylor \& Francis, 3-23.

Kellehear, A. 1984. "Are We a 'Death-Denying' Society? A Sociological Review," Social Science and Medicine, 18.9, 713-23.http://dx.doi.org/10.1016/0277-9536(84)90094-7

Mitchell, K. 2004. "Geographies of Identity: Multiculturalism Unplugged," Progress in Human Geography, 28.5, 641-65. http://dx.doi.org/10.1191/0309132504ph510pr

Phinney, J. S., G. Horenczyk, K. Liebkind and P. Vedder. 2001. "Ethnic Identity, Immigration and Well-being: An Interactional Perspective," Journal of Social Issues, 57.3, 493-510. http://dx.doi.org/10.1111/0022-4537.00225

Robinson, L. 2009. "Cultural Identity and Acculturation Preferences among South Asian Adolescents in Britain: An Exploratory Study," Children and Society, 23.6, 442-54. http://dx.doi.org/10.1111/j.1099-0860.2008.00179.x

Schneider, M. 1991. History of a Jewish Burial Society: An Examination of Secularization. Lewiston, New York, Lampeter: Edwin Mellen Press.

Seale, C. 1998. Constructing Death: The Sociology of Dying and Bereavement. Cambridge: Cambridge University Press. http://dx.doi.org/10.1017/CBO9780511583421

Sharot, S. 2011. "Judaism and Jewish Ethnicity: Changing Interrelationships and Differentiations in the Diaspora and Israel," in E. Krausz and G. Tulea, eds, Jewish survival: The Identity Problem at the Close of the Twentieth Century. London: Transaction, 87-105.

Taylor, C. 1997. "The Politics of Recognition," in A. Heble, D. Palmateer Pennee and J. R. Tim Struthers, eds, New Contexts of Canadian Criticism. Peterborough, Ontario: Broadview Press, 25-73.

Verkuyten, M. 2005. The Social Psychology of Ethnic Identity. Hove: Psychology Press. http:// dx.doi.org/10.4324/9780203338704

Walter, T. 1999. On Bereavement: The Culture of Grief. Buckingham: Open University Press.

Zimmermann, C., and G. Rodin. 2004. "The Denial of Death Thesis: Sociological Critique and Implications for Palliative Care," Palliative Medicine, 18.2, 121-28. 